\title{
Monitoring public awareness about the endangered northern bald ibis: a case study involving primary school children as citizen scientists
}

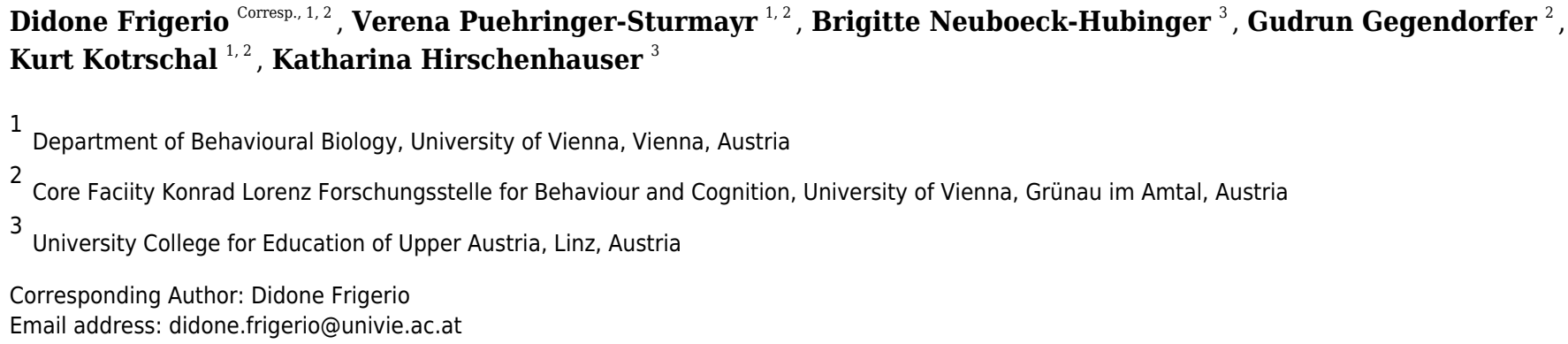

Background. Citizen science has evolved over the past decades by motivating members of the public to interact with scientists and actively participate in scientific research and monitoring. For this purpose, a proficient communication is mandatory in order to efficiently convey messages and reduce the gap of knowledge between scientists and lay people. In the present study, we aimed at evaluating the multiplying effect of children, who were trained to communicate their knowledge on an endangered bird species in order to engage the local community in the long-term ornithological monitoring of the free flying and individually marked colony of northern bald ibis (NBI, Geronticus eremita), which was established at the research station in 1997. Methods. Pupils of the local primary schools were in regular contact with researchers, enjoyed outdoor encounters with the birds, and were invited to talk about their experience with as many people as possible. Later on, they acted as surveyors to assess the knowledge of the public on (i) the general knowledge about the species, (ii) specific knowledge about the local colony, and (iii) attitudes towards science. In two different years of evaluation (2012 and 2016) a total number of 387 persons were surveyed. The questions were generated together with the pupils and their teachers and the questionnaires were similar for both years of evaluation. All queries were in a closed format. Results. Our results show an increase in the proportion of correct answers provided by the surveyed persons between the two years of evaluation. Education-based activities may encourage children to effectively act as multipliers of information and attitudes. This has the potential to induce sustainable changes with respect to attitude towards science, at least among local communities. Furthermore, the study suggests caution with the quality of some information reported by citizen scientists, which might be solved by more careful training actions and more specific information 
about local particularities. Even though the study would have gained more informative power with some additional precautions than in its current form, our findings recommend the empowerment of pupils as multipliers of scientific knowledge. 
1 Title:

2 Monitoring public awareness about the endangered northern bald ibis: a case study involving primary

3 school children as citizen scientists

4

5 Authors:

$6 *^{*}$ Didone Frigerio ${ }^{1,2}$, Verena Puehringer-Sturmayr ${ }^{1,2}$, Brigitte Neuböck-Hubinger ${ }^{3}$, Gudrun Gegendorfer ${ }^{1}$,

7 Kurt Kotrschal ${ }^{1,2}$, Katharina Hirschenhauser ${ }^{3}$

8

9 Authors' affiliations and current addresses:

$10{ }^{1}$ Core facility Konrad Lorenz Forschungsstelle for Behaviour and Cognition, University of Vienna,

11 Fischerau 11, A-4645 Grünau im Almtal, Austria.

$12{ }^{2}$ Department of Behavioural Biology, University of Vienna, Althanstrasse 14, A-1090 Vienna, Austria.

$13{ }^{3}$ University College for Education of Upper Austria, Kaplanhofstraße 40, 4020 Linz, Austria.

14

*Corresponding author: didone.frigerio@univie.ac.at; Core facility KLF, University of Vienna, Fischerau

11, A-4645 Grünau im Almtal, Austria.

17

\section{Short title:}

Citizen scientists as knowledge multipliers

\section{Keywords:}


24 Word count: 8169

25 


\section{Abstract:}

Background. Citizen science has evolved over the past decades by motivating members of the public to interact with scientists and actively participate in scientific research and monitoring. For this purpose, a proficient communication is mandatory in order to efficiently convey messages and reduce the gap of knowledge between scientists and lay people. In the present study, we aimed at evaluating the multiplying effect of children, who were trained to communicate their knowledge on an endangered bird species in order to engage the local community in the long-term ornithological monitoring of the free flying and individually marked colony of northern bald ibis (NBI, Geronticus eremita), which was established at the research station in 1997.

Methods. Pupils of the local primary schools were in regular contact with researchers, enjoyed outdoor encounters with the birds, and were invited to talk about their experience with as many people as possible. Later on, they acted as surveyors to assess the knowledge of the public on (i) the general knowledge about the species, (ii) specific knowledge about the local colony, and (iii) attitudes towards science. In two different years of evaluation (2012 and 2016) a total number of 387 persons were surveyed. The questions were generated together with the pupils and their teachers and the questionnaires were similar for both years of evaluation. All queries were in a closed format.

Results. Our results show an increase in the proportion of correct answers provided by the surveyed persons between the two years of evaluation. Education-based activities may encourage children to effectively act as multipliers of information and attitudes. This has the potential to induce sustainable changes with respect to attitude towards science, at least among local communities. Furthermore, the study suggests caution with the quality of some information reported by citizen scientists, which might be solved by more careful training actions and more specific information about local particularities. Even though the study would have gained more informative power with some additional precautions than in 
49 its current form, our findings recommend the empowerment of pupils as multipliers of scientific 50 knowledge.

51 


\section{Introduction}

53 Surveys on the public understanding of science in Western communities show that a majority of people

54 cannot perceive the social impact of scientific findings, which unravels a communication gap between scientists and lay persons (i.e. members of the public; Bensaude-Vincent, 2001; Pardo and Calvo, 2002). As a consequence, communicating science to the general public and responding to public demands

57 about knowledge is increasingly recognized as a responsibility of scientists (Greenwood, 2001; Leshner, 2003; Brownell et al., 2013). The aim to effectively promote levels of general knowledge and scienceaffinity in society via understanding science is indeed a challenging task (Racine et al., 2005; Illes et al., 2010; Keehner and Fischer, 2011). Yet, the effectiveness of educational initiatives strongly depends on the strategies scientists adopt in order to interactively communicate research interests and novel insights to the public (Van der Sanden and Flipse, 2016; Rauchfleisch and Schäfer, 2018). However, Binder et al. (2012) suggested that both, low levels of public attention for science and a lack of civic participation in scientific activities can nullify the process of science communication (Medvecky and Leach 2017; Wilkinson, 2018). On the other hand the interaction between lay people and scientists, as well as the active participation of people in scientific research are recently gaining attention worldwide

67 (Shirk et al., 2012; Frigerio et al., 2018) and this indeed benefits science communication (Constant and Roberts, 2017).

Over the past decades, citizen science has developed active involvement of interested amateurs in a wide range of disciplines, e.g. by reporting observations, taking measurements or analysing data, at different stages of scientific projects. Evaluation programmes have shown that in addition to the spread of scientific facts and understanding (Brossard et al., 2005; Trumbull et al., 2005), some participants have substantially contributed in developing experimental designs and/or formulating research questions, as well as objective conclusions (Trumbull et al., 2000). Involving people from within and outside academia is not entirely new, as for example bird-watching activities may be considered 
worldwide among the first citizen science programmes (Irwin, 1995; Bonney and La Branche, 2004).

However, education-based activities can be considered a promising emerging field in citizen science (Wiggins and Crowston, 2011). They aim especially at increasing scientific literacy and raising awareness about conservation issues (Bela et al., 2016; Bonney et al., 2009). Such projects are beneficial for all groups of participants and bear a still untapped potential (Frigerio et al., 2018). For instance, Hirschenhauser et al. (2016) showed that the specific knowledge and interest acquired by pupils during extracurricular science education activities in the frame of citizen science projects were retained over longer periods than usual as compared to the performance of a control group which was not involved in the citizen science activities. In fact, the participatory training effects lasted at least over a period of nine weeks, which corresponded to the summer holidays break in the country where the investigation was conducted. Thus, citizen science is suitable for education as long as it is complementary to the curriculum proposed by school authorities, as for instance by providing relevant opportunities for the application of previously abstract knowledge to the pupils' lived experiences (e.g. informal education occurring on top of a structured curriculum, Wilde et al.; 2012; Rogoff et al., 2016).

The northern bald ibis (Geronticus eremita, NBI) was listed as critically endangered since 1994. Due to the positive development of the last wild population in Morocco, the species was recently downgraded to endangered (BirdLife International, 2018). Among several conservation projects started in the past years (Boehm and Pegoraro, 2011), a sedentary, free roaming, individually marked and semi-tame NBIcolony was established in 1997 at the Konrad Lorenz Research Station (KLF, Grünau im Almtal, Upper Austria; $47^{\circ} 48^{\prime} \mathrm{E}, 13^{\circ} 56^{\prime} \mathrm{N}$ ) by hand-raising zoo-bred chicks (Tuckova et al., 1998; Kotrschal, 2007) in coordination with the European Breeding Programme (Boehm, 1999). The KLF still provides important research results about the social behaviour of these colony breeders (Puehringer-Sturmayr et al., 2018; Frigerio et al. 2017; Tintner and Kotrschal, 2002), contributing know-how for different NBI conservation 
99

100

101

102

103

104

105

106

107

108

109

110

111

112

113

114

115

116

117

118

119

120

121

122

projects in the past years, as for instance the human-led-migration by the Waldrappteam (waldrapp.eu;

Fritz and Unsoeld, 2015) or the reintroduction in Spain (Quevedo et al., 2004).

The KLF-flock of NBI is housed in a large breeding aviary, which is kept open year-round, allowing the birds to roam the feeding grounds in the region. During times of frost or snow cover the birds are provided with supplementary food. In the frame of a research project involving several schools of the region (from kindergarten to high school), children acted as knowledge multipliers in order to inform the native people how to participate in the monitoring of the local avian population and to provide information about the sightings of individual NBI on the meadows of the valley. School children were involved in manyfold indoor and outdoor activities (i.e. in the classroom and in the field, see methods section for more details) aiming at fostering their content knowledge on the species. In both years of evaluation, the participating children experienced regular contacts with the researchers and outdoor encounters with the birds, as well as input by visiting professional experts. With the expertise of recognizing juvenile and adult birds, as well as individual ones, the pupils were then encouraged to act as multipliers of knowledge in the village by sharing the information with their families and telling as many persons as possible about their lived experiences. After six months of scientific inputs, the knowledge of the local community on NBI was assessed by involving pupils of the local primary schools as interviewers (paper-pencils questionnaires) with two very similar questionnaires run in two different years, in 2012 (pilot-project) and 2016. The participating children were conducting the surveys face-toface and later on they were joining the scientists for the analysis and the discussion of the results. We aimed at assessing differences in the knowledge about the local NBI population and gaining experience in targeting educational activities, as well as the quality of the information provided to the local community (science to public and vice-versa). Overall, due to the long-term presence of the research station in the valley, its regular press releases, as well as the resonance of the citizen science activities with the children (Frigerio et al., 2012), we expected people to be aware of NBI research. We expected 
123 the children's activities to contribute setting up an emotional relationship between the village and the

$124 \mathrm{KLF}$ and fostering interest for its research activities. Results are discussed with respect to lessons learnt 125 and possible improvements.

Methods

\section{Ethical statement}

This study complies with all current Austrian laws and regulations concerning working with wildlife.

Animal observations were performed under Animal Experiment License Number 66.006/0026-

that the owner of the land, the Duke of Cumberland, gave permission to conduct behavioral studies on College of Education (30.04.2015). In addition, we asked for consent from the legal school authorities.

The main research interests of the KLF are physiological and cognitive mechanisms underlying social life

141 in avian species. Notwithstanding, the KLF is also engaged for years in promoting young talents and

142 knowledge transfer with the main aim of fostering awareness and gaining acceptance in the local

143 community.

144 The present study was conducted in two different years: a first time as a pilot-project in 2012 (where

145 only adults were surveyed) and a second time with minor modifications in 2016 (when also children

146 were involved). In both years of evaluation the pupils were actively joining in a research project on NBI. 
147 In this context, the researchers offered regular scientific input to the participating classes (at least once

148 per month) for a total of 10 months spread over two school-years (i.e. 5 months per year). At the

149 beginning of the project the researchers (DF, GG) visited the children at school and introduced them to

150 the bird species, its specific behavior and the research questions (Puehringer-Sturmayr et al. 2018). The

151 pupils were trained to identify the species, to distinguish the age of the birds (i.e. as juveniles or adults),

152 as well as to spot individuals by the color combination of the rings on their legs (Frigerio and

153 Gegendorfer, 2013). Afterwards, the pupils were visiting the Konrad Lorenz Research Station and

154 enjoyed their first close contact with the free-roaming birds, fulfilling the same tasks as at school, i.e.

155 distinguishing individual birds by the colored leg rings and observing their behavior. The pupils also

156 visited the local game park, where they had the opportunity to enter the aviary together with the

157 scientists. Furthermore, they were able to improve their skills in identifying individual birds during an

158 excursion around the area (Frigerio and Gegendorfer, 2013). Finally, two international NBI experts

159 visited the schools and presented their work. The participating pupils met the local researchers a total of

160 eight times. In between, they were encouraged to tell as many people as possible about their

161 experiences with the research project. Later on, both the pupils and their teachers were directly

162 involved in generating the questions for the survey. In 2016 it was generally opted for keeping the 2012-

163 questions and the school classes were asked if they wanted to add further queries.

164 Therefore, the questionnaires were similar for both years of evaluation; the total number of questions

165 was 14 in 2012 and 15 in 2016. All queries were in a closed format, i.e. a choice among three (2012,

166 "yes", "no", "I do not know") or five (2016, "yes" and "rather yes", as well as "no" and "rather no" and "I

167 do not know") answers was required. "Rather yes" and rather no" were provided to better approach

168 people that could have been unsure about a clear "yes" or "no" answer. Post-hoc, in order to compare

169 the results of the two years of investigation, the answers "yes" and "rather yes", as well as "no" and

170 "rather no" of the 2016-questionnaires were pooled into "yes" and "no" respectively.

Peer) reviewing PDF | (2019:01:34668:1:1:NEW 24 Jun 2019) 
171 In 2016 one open question was added ("How well do you feel informed about the local NBI colony?"). In

172 both years of data collection, the questionnaires had two main foci: (1) general knowledge on NBI

173 biology and (2) specific knowledge on the NBI population of the KLF. In 2016 a third focus was added

174 (i.e. the public attitude toward scientific research (sensu Jones et al., 2000)). Questions and correct

175 answers from both years of evaluation, 2012 and 2016, are presented in Tab. 1. Five of the six questions

176 (1 to 5) had a clear "correct" answer, i.e. "yes" (questions 1, 2 and 5) or "no" (questions 3 and 4). None

177 of the possible answers for question 6 could be assessed as correct or not, as the query dealt with the

178 subjective perception of information on the NBI.

179 In the two different years of evaluation a total number of 387 persons were surveyed. In 2012 thirteen 180 pupils aged 9 to 10 years of the local primary school (school A) surveyed a total of 67 adults (i.e. older

181 than 18 years; 30 men and 37 women). No additional information about the age of the surveyed people

182 was collected in 2012. In 2016 forty-eight pupils aged between 9 and 10 years of two local primary

183 schools (school A and school B) surveyed a total of 320 people including children in legal school age (i.e.

1847 to 16 years old; $n=156,66$ boys and 90 girls; mean age $\pm S D=10.40 \pm 2.75$ ) and adults (i.e. older than

18518 years; $n=164,75$ men and 89 women; mean age $\pm S D=52.92 \pm 17.61$ ). The children had free choice

186 about how to pick the people for their surveys. Depending on the age of the pupils, some teachers

187 preferred to give the survey as a homework over a longer period of time, whereas others, with younger

188 pupils, chose to use excursions in the village to ask people for answers. The questionnaires were

189 anonymous; however, the children were instructed to make sure that each person was only asked once.

190 For this purpose, they were directly asking the surveyed person if that was his/her first participation in

191 the survey. Therefore, we can exclude that anybody was asked twice, at least within the same year of

192 investigation.

193 All statistical analyses were done by R version 3.5.1 (R Core Team, 2018), using the packages "Ime4"

194 (Bates et al., 2015) for generalized linear models and "ggplot2" (Wickham 2016) for visualizations. To

Peer] reviewing PDF | (2019:01:34668:1:1:NEW 24 Jun 2019) 
195

196

197

198

200

201

202

203

204

205

206

207

208

209

210

211

212

213

214

215

216

217

218

look for differences between the two years of investigation and to test whether people that felt well informed, were also able to answer more correct questions, we defined the queries 1 to 5 as single response variables and the interaction term query 6 (specific knowledge: I feel well informed about the local NBI colony) and year as fixed factor. Furthermore, to analyse whether the perception of feeling well informed changed over the years of evaluation, query 6 was defined as response variable and year as fixed factor. For the analyses we used generalized linear models with a binomial distribution and logit link function. The results are presented as percent of change(delta) of correct, vague and wrong answers between the two years of data collection. This was done within the group of adult people. In the case of the children, who were only surveyed in 2016, results are presented as proportions (percentages) of correct answers for each of the main foci of the questionnaires separately.

\section{Results}

In general, in both investigated foci, i.e. the general and specific knowledge on NBI, the proportion of correct answers was higher in the second year of evaluation as compared to the first year of data collection (Figs. 1 and 2). In 2012, 58.2\% of the surveyed adults were aware that NBI are colony breeders; in 2016 a higher proportion of adults (76,3\%; Fig. 1A) and 69,7\% of the children (surveyed in 2016 only; Fig. 3A) correctly answered this question. The same trend was found for the question about the conservation status (NBI are critically endangered, Fig. 1B): in 2012, 70.2\% of the surveyed people were aware of this, and a higher proportion of adults (89\%) in 2016 , whereas the result for the surveyed children was $77.6 \%$.

Most of the surveyed people were aware of the possibility of sighting the birds on the meadows of the valley (74.6\% in 2012, 91.9\% adults and $88.4 \%$ children in 2016; Figs. 2B and 3E respectively). Furthermore, in $2012,43.3 \%$ of the people felt well informed about the local NBI free flying colony, whereas in $201656.7 \%$ adults and $61.2 \%$ children felt did so. 
219 We found a trend that more people gave the correct answers in 2016 when they had the feeling to be

220 well informed about the local NBI colony (specific NBI knowledge, query 5). However, the reverse trend

221 was observed when asking people how to distinguish juvenile from adult birds (general NBI knowledge,

222 query 3): in 2012 people were more aware of the morphological differences between adult and juvenile

$223 \mathrm{NBI}$ (34.3\% in 2012, adults only) than the people surveyed in 2016 ( $19.6 \%$ adults and $22.4 \%$ children,

224 Figs. 1C and 3C, Table 3 and 4). The rates of correct answers for queries 1, 2 and 4 were not significantly

225 different between years, i.e. the variation of the explanatory variables was not better explained by the

226 full model than the null model (Tabs. 3 and 4). Also query 4 about the migratory habits of the local

227 colony was answered correctly ("no" in this case) by $22.4 \%$ of adults in 2012 , and by $34.7 \%$ of the adults

228 and $32.6 \%$ of the children in 2016 (Figs. 2A and 3D respectively).

229 Results related to the third focus are available only for 2016 (Tab. 2): the majority of people thought

230 that scientific research ( $94 \%$ and $97 \%$ of the asked adults and children, respectively), as well as

231 conservation was important for society ( $99 \%$ and $97 \%$ of the asked adults and children, respectively).

232 Yet, $13 \%$ of the adults and $16 \%$ of the school-aged children noted that they were doubtful about the

233 trustworthiness of scientific results.

\section{Discussion}

236 In the present study, the percentage of correct answers provided in most of the questions asked

237 increased between the two years of evaluation (i.e. over the four study years). Overall in the second

238 year (2016) a smaller proportion of people answered with "I do not know" than in the first year (2012).

239 They rather selected a clear "yes" or "no". Even though we cannot exclude that the children running the

240 survey somehow influenced the answers they received, such evidence might hint to less insecurity by

241 the people when choosing an answer, suggesting that in 2016 people were more confident in their NBI

242 knowledge than in the year 2012. 
243 Overall the findings suggest that the educational activities successfully contribute to a lasting awareness

244 on NBI and scientific research by the local community. Though not directly tested in the present study,

245 the link between correct answers and efficacy of educational activities is plausible. However, adding

246 some more detailed questions in 2016 , i.e. in the second year of evaluation, would have increased the

247 informative power of the study considerably. For this purpose, questions like "Did you take part in any

248 of the listed activities..."; "did you read about the NBI population in the newspaper", or "did you report

249 bird sightings" would have been helpful for better understanding the patterns observed.

250 The proposed activities included workshops in the classrooms and hands-on exercises with free ranging

251 birds in the field. Detailed information about the contents of such activities are published elsewhere and

252 included a mix of lecture-style teaching, interactive workshops and hands-on activities (NBI, Frigerio and

253 Gegendorfer, 2013; greylag geese, Frigerio et al., 2014; common ravens, Beck et al., 2016). Active hands-

254 on involvement may even be more effective than interactive workshops, as recently suggested by

255 Hesley et al. (2017) in a programme for reef restoration. There, participants were trained in reef

256 restoration by unique, experiential learning opportunities to recover degraded corals. Additional surveys

257 among the participants confirmed a significant improvement of their knowledge about coral reef

258 ecology (Hesley et al. 2017). Although few studies have rigorously assessed the role of citizen science in

259 changing participants' attitudes, fostering scientific literacy is often considered a "by-product" of citizen

260 science activities, (e.g. Crall et al., 2012). For example, Miczajka et al. (2015) claim that the children

261 involved in a scientific project on seed predation indeed deepened their understanding of the ecology of

262 plant-animal interactions. Furthermore, the participation in such a citizen science project accomplished

263 the requirements of the national school curriculum and provided a valuable opportunity to connect

264 school and community by science learning (Bouillion and Gomez, 2001). However, research on learning

265 by experience (i.e. effects of hands-on experiences on students' interests and attitudes) has a long history

266 in the field of science education (Bergin 1999). Even though there is a general consensus that hands-on

PeerJ reviewing PDF | (2019:01:34668:1:1:NEW 24 Jun 2019) 
267 experiences foster students' learning effectiveness (Satterthwait, 2010), there is evidence suggesting

268 that the performance of various hands-on activities can influence students' interest differently

269 (Holstermann et al., 2010). Therefore, the positive influence of hands-on activities on students' interest cannot be generalised to every activity, but seems to be rather context-dependent (Sjøberg and

271 Schreiner, 2005; Holstermann et al., 2010).

272 Even though the education-based activities had effects on the people's awareness and interest in NBI, some aspects of $\mathrm{NBI}$ were not clearly transmitted to the local public knowledge. For example, the percentage of correct answers to the question about the migratory tradition of the local bird population was continuingly rather low $(<30 \%)$, but still increased between the two years of evaluation (Fig. 2). The NBI flock of the KLF does not migrate. However, the birds spend most of the winter in the aviary of the local game park, where they get fed. Although they could, the birds rarely visit the meadows in the village during the winter months. Therefore, during winter they can be rarely observed by the local community as free-roaming in the area. Furthermore, the surveyed people probably thought of reports from the human led migration of another NBI colony by the Waldrappteam (waldrapp.eu/), an organisation aiming at reintroducing migrating NBI in Europe since 2003 (Portugal et al., 2014; Fritz and Unsoeld, 2015). This reintroduction project originally developed out of KLF activities, has a strong media presence ever since and may therefore not be distinguished easily from present KLF-related NBI activities by many locals.

According to our study, the surveyed people seem to be reasonably aware of the endangered status of

to the impact of the project per se; however, the latter is indeed a locally relevant topic, as the research of the KLF focuses on investigating NBI social behaviour. Results about how to distinguish between adult and juvenile animals (Fig. 1C) suggest the need for emphasizing observation and ornithological skills in 
291 information on the age of the birds. The sightings are an important part of the long-term monitoring of

292 the KLF and are relevant for generating and answering research questions about habitat use and social

293 behaviour of the colony (e.g. do the birds choose the foraging meadows depending on traditions, i.e.

294 site fidelity, or on habitat quality?). However, mainly because of lacking financial and personal resources

295 this aspect of NBI's behavioural ecology has not been investigated exhaustively yet and it would be best

296 suitable for a citizen science project (Dickinson et al., 2018). In a follow-up project, an App with childlike

297 design (WaldrApp, https://www.citizen-science.at/aktuelleprojekte/item/310-waldrapp) was launched

298 in the region, in order to systematically collect sightings from citizen scientists. In this case, it is

299 mandatory to upload a picture of the bird, so that the researchers may judge the correctness of the

300 information.

301 Concern about data reliability remains a major issue in citizen science projects (Kremen et al., 2011).

302 However, different approaches show that data collected by citizen scientists do not consistently differ

303 from those collected by professional researchers (Cohn, 2008; Schmeller et al., 2009; Miczajka et al.,

304 2015; Puehringer-Sturmayr et al., 2018). Therefore, we are confident that a careful and specific training

305 will improve the reliability of the sightings as suggested by other studies on biodiversity (Kelemen-Finan

306 et al., 2018).

307 Encouraging children to act as multipliers may not be sufficient to induce significant attitude changes in

308 the local population. However, there is evidence that detailed extracurricular experiences effectively

309 produced long-term concept changes in pupils participating in the school project opportunities offered

310 by the KLF (Hirschenhauser et al., 2016).

311 The last question on how well the people felt informed about the local NBI colony (less than $61 \%$

312 positive answers) indicates the need and the wish for more frequent and more targeted communication

313 activities by the scientists (e.g. exhibitions and/or public seminars, science cafes), at least at the local

314 level. In fact, the four years of educational activities did produce some changes in the perception of the 
315 topic and in the general awareness about NBI. Still, our results of the 2016 survey also show a

316 considerable proportion of people unwilling to fully trust scientific results. How much this was related to

317 our activities remains unclear, as our focal targets for communication were the pupils in schools as

318 natural multipliers of information. The multiplier role for the pupils was beneficial for the aim of the

319 study, as persons familiar and non-familiar with the surveying children were equally motivated to

320 support them in their task. Therefore, involving pupils as multipliers might be a promising approach to

321 induce the attention of the local population for scientific research in general and for the KLF's research

322 activities specifically. This approach contributed to a peer-to-peer context during the street surveys, as

323 none of the parties was a professional researcher.

324 On the other hand, the transfer of knowledge from the scientists to the pupils might be perceived as a

325 top-down event aiming at a "training the trainer" effect in order to promote a participatory learning

326 community. Both these aspects might contribute to disentangling the thresholds between critical

327 thinking and general mistrusting in scientific evidence in adult people, whereas children seem to be

easier in filling themselves with enthusiasm for a specific subject. Peer-to-peer activities involve sharing

of knowledge and foster the awareness of participation and responsibility for one's own and others'

learning (i.e. public knowledge, Boud et al., 1999).

Probably due to the teachers' imperative to keep the surveys simple and age-appropriate as well as to

our limited experience when working with pupils, our study design lacks some informative power.

Indeed, the questions had to be kept simple for the children. Additionally, attribution of impact to the

effects of particular research activities is always a challenge when multiple sources of influence are

invovled. However, in order to better disentangle the effects of the educational activities promoted by

the children from the communication initiatives run by the research station (reports in public media,

337 presence in schools), it would have been important to add some questions asking the surveyed people 
339 their knowledge elsewhere. Such additional queries would have contributed to understand where from

340 and how this particular community receives information effectively. Another meaningful improvement

341 might have been to include a complementary survey without the children - for example ask the same

342 questions in a postal or online survey (which explicitly asked the respondent whether they have had

343 contact with the children involved in the work). This would have provided some 'control' set of

344 observations for the suggested efficacy of the children as knowledge multipliers, as children were

345 supposed to act as multipliers before the surveys. A further improvement would have been to employ

346 additional open format questions to supplement the queries 7 to 9, as for instance 'Why do you (not)

347 trust in scientific findings?', which would enable a better interpretation of the 'yes' and 'no' answers.

348 Our results suggest a major role for the knowledge multipliers in spreading information and promoting

349 societal changes, although at a small scale. The concept of knowledge multipliers is a research topic also

350 in economics science focusing on the rate of technological change (da Silva, 2014). The same concept

351 can be applied in citizen science: for instance, in the "Austrian roadkill project", Heigl and Zaller (2014)

352 showed that the participants monitoring dead animals along the streets could improve their

353 understanding of wildlife and conservation issues. They were also willing to share their awareness with

354 others. Thus, voluntary people acted as knowledge multipliers and thereby contributed to public

355 awareness of the topic of the project and of citizen science in general. Therefore, engaging the public in

356 the scientific process may contribute to recognize the wider contexts of science, including culture and

357 policy (Bonney et al., 2009; Mitchell et al., 2017).

358 In sum, our results hint at a pivotal role for research initiatives to communicate to, and also, involve lay

359 persons. 
361

362

363

364

365

366

367

368

369

370

371

372

373

374

375

376

377

378

379

380

381

382

383

384

385

386

\section{Conclusions}

Our findings show that education-based activities may encourage children to effectively act as multipliers of information and of attitudes. Potentially, this will induce sustainable changes, e. g.

changes of attitudes towards science and trust in scientific results, at least among local communities.

Furthermore, the study suggests caution with some of the information reported by citizens, which might be solved by more careful training actions and more specific information about local particularities. We highly recommend long-term engagement with a (regional) community, as this can ensure a sustainable willingness to cooperate. In fact, people need time to become confident with, and identify themselves, with a specific topic, such as for instance the nature of scientific research. Integrating children as researchers to poll adults for their knowledge about a biodiversity topic might be considered as an educative initiative appropriate for young people's growing request to engage in society and global environmental concerns. Furthermore, it seems important to choose focal issues or relevant questions which are of mutual interest for scientists and local communities or part of their everyday experiences (Ries and Oberhauser, 2015). Finally, active participation of citizens in research activities, such as conducting research with children and across generations is mandatory for an effective research communication. On these grounds, education-based activities have the potential to benefit all parties involved, that is research, education and society.

\section{References}

Bates, D., Maechler, M., Bolker, B., and Walker, S. (2015). Fitting Linear Mixed-Effects Models Using Ime4. Journal of Statistical Software, 67, 1-48

Beck, K., Frigerio, D. and Loretto, M.C. (2016). Der Kolkrabe - Schwarzfedriges Genie oder doch nur ein Unglücksbote? - Von Irrtümern und Mythen bis hin zur Forschung von Groß und Klein. Öko-L 38(1): 3-11.

Bela, G., Peltola, T., Young, J. C., Balázs, B., Arpin, I., Pataki, G., Hauck, J., Kelemen, E., Kopperoinen, L., Van Herzele, A., Keune, H., Hecker, S., Suškevičs, M., Roy, H. E., Itkonen, P., Külvik, M., László, M., 
387 Basnou, C., Pino, J., and Bonn, A. (2016). Learning and the transformative potential of citizen science.

388 Conservation Biology, 30: 990-999.

389 Bensaude-Vincent, B. (2001). A genealogy of the increasing gap between science and the public. Public 390 Understanding of Science, 10: 99-113. doi 10.3109/a036858.

391 Bergin, D. A. (1999). Influences on classroom interest. Educational Psychologist, 34, 87-98.

392

393

394

395

396

397

398

399

400

401

402

403

404

405

406

407

408

409

410

411

412

413

414

415

416

417

418

419

420

421

422

423

424
Binder, A. R., Scheufele, D. A. and Brossard, D. (2012). Misguided science policy? The pitfalls of using public meetings as surrogate gauges of public opinion. The Scientist, 4; http: //thescientist.com/2012/04/10/opinion-misguided-science-policy.

BirdLife International 2018. Geronticus eremita. The IUCN Red List of Threatened Species 2018: e.T22697488A130895601. http://dx.doi.org/10.2305/IUCN.UK.2018-2.RLTS.T22697488A130895601.en. Downloaded on 05 December 2018.

Boehm, C. (1999) Ten years of Northern bald ibis EEP: a review. In: Boehm C (ed) 2nd International EEP Studbook. Alpenzoo, Innsbruck, pp 73-88.

Boehm, C. and Pegoraro, K. (2011): Der Waldrapp, Geronticus eremita- ein Glatzkopf in Turbulenzen. Band 659 aus der Reihe „Die Neue Brehm-Bücherei“, Westarp Wissenschaften Verlag.

Bonney, R. and La Branche, M. (2004). Citizen science: Involving the public in research. ASTC Dimensions, p. 13.

Bonney, R., Cooper, C. B., Dickinson, J., Kelling, S., Phillips, T. B., Rosenberg, K. V., and Shirk, J. (2009). Citizen Science: A developing tool for expanding science knowledge and scientific literacy. Bioscience, 59: 977-984.

Boud, D., Cohen, R. and Sampson, J. (1999). Peer Learning and Assessment, Assessment \& Evaluation in Higher Education, 24: 4, 413-426, DOI: 10.1080/0260293990240405

Bouillion, L.M., Gomez, L.M. (2001). Connecting school and community with science learning: Real world problems and school-community partnerships as contextual scaffolds. Journal of Research in Science Teaching, 38: 878-898.

Brossard, D. Lewenstein, B. and Bonney, R. (2005). Scientific knowledge and attitude change: The impact of a citizen science project. International Journal of Science Education, 27(9): 1099-1121.

Brownell, S. E., Price, J. V., \& Steinman, L. (2013). Science communication to the general public: Why we need to teach undergraduate and graduate students this skill as part of their formal scientific training. Journal of Undergraduate Neuroscience Education, 12(1): E6-E10.

Cohn, J. (2008). Citizen science: Can volunteers do real research? BioScience, 58: 192-7.

Constant, N. \& Roberts, L. (2017). Narratives as a mode of research evaluation in citizen science: understanding broader science communication impacts. JCOM 16 (04), A03.

Crall, A. W., Jordan, R., Holfelder, K., Newmann, G. J., Graham, J., \& Waller, D. M. (2012). The impacts of an invasive species citizen science training program on participant attitudes, behavior, and science literacy. Public Understanding of Science, 0 (0): 1-20.

da Silva, M. A. P. M. (2014). The knowledge multiplier. Economics of Innovation and New Technology, 23: 7, .652-688, DOI: 10.1080/10438599.2014.882138

Peer] reviewing PDF | (2019:01:34668:1:1:NEW 24 Jun 2019) 
425

426

427

428

429

430

431

432

433

434

435

436

437

438

439

440

441

442

443

444

445

446

447

448

449

450

451

452

453

454

455

456

457

458

459

460

461

462

463

464

465
Dickinson, J. L., Shirk, J., Bonter, D., Bonney, R., Crain, R. L., Martin, J., Phillips, T. and Purcell, K. (2012). The current state of citizen science as a tool for ecological research and public engagement. Frontiers in Ecology and the Environment, 10: 291-297. doi:10.1890/110236

Frigerio, D., Pipek, P., Kimmig, S., Winter, S., Melzheimer, J., Diblíková, L., Wachter, B. and Richter, A. (2018). Citizen science and wildlife biology: Synergies and challenges. Ethology, 4, e6968. doi.org/10.1155/2012/710710.

Frigerio, D., Cibulski, L., Ludwig, S. C., Campderrich, I., Kotrschal, K. and Wascher, C. A. F. (2016). Excretion patterns of coccidian oocysts and nematode eggs during the reproductive season in Northern Bald Ibis (Geronticus eremita). Journal of Ornithology, 157(3): 839-851. doi:10.1007/s10336-015-1317-z.

Frigerio, D., Hemetsberger, J. and Kotrschal, K. (2014). Selbst nach 40 Jahre Forschung: Neues von den grünauer Graugänsen - Von internationaler Grundlagenforschung bis zur Zusammenarbeit mit Volksschulkindern. Öko-L. 36(1): 3-13.

Frigerio, D. and Gegendorfer, G. (2013). Exotisch oder heimisch? - Der Waldrapp aus dem Almtal. Groß und Klein erforschen die vom Aussterben bedrohte Vogelart. Öko-L 35(3): 3-13.

Frigerio, D., Kotrschal, K., Millesi, E. and Hemetsberger, J. (2012). Children and scientific observations: pupils measuring Greylag goose behaviour. International Journal for Cross Disciplinary Studies in Education, 3: 871-876.

Fritz, J. and Unsoeld, M. (2015). Internationaler Artenschutz im Kontext der IUCN Reintroduction Guidelines: Argumente zur Wiederansiedlung des Waldrapps. Vogelwarte 53: 157 - 168.

Greenwood, M. R. C. (2001). Civic scientist/Civic Duty. Science Communication 23: 28-40.

Heigl, F., and Zaller, J. G. (2014). Using a Citizen Science Approach in Higher Education: a Case Study reporting Roadkills in Austria. Human Computation 1(2): 165-175.

Hesley, D., Burdeno, D., Drury, C., Schopmeyer, S. and Lirman, D. (2017). Citizen science benefits coral reef restoration activities. Journal for Nature Conservation 40: 94-99, https://doi.org/10.1016/j.jnc.2017.09.001.

Hirschenhauser, K., Frigerio, D., and Neuböck-Hubinger, B. (2016). Wirkungen außerschulischer Angebote im Sachunterricht: das Waldrapp-Projekt - Impact of external projects on teaching natural sciences in primary school: the Northern bald ibis case. In: Transfer Forschung-Schule, Band 2: Visible Didactics - Fachdidaktische Forschung trifft Praxis (J. Klinkhardt ed.). Bad Heilbrunn, Austria, pp. 307308.

Holstermann, N., Grube, D., and Bögeholz, S. (2010). Hands-on Activities and Their Influence on Students' Interest. Res. Sci. Educ. 40: 743. https://doi.org/10.1007/s11165-009-9142-0

Illes, J. Moser, M. A., McCormick, J. B., Racine, E., Blakeslee, S., Caplan, A., Hayden, E. C., Ingram, J., Lohwater, T., McKnight, P., Nicholson, C., Phillips, A., Sauve, K. D., Snell, E. and Weiss, S. (2010). Neurotalk: improving the communication of neuroscience research. Nat. Rev. Neurosci. 11: 61-69.

Irwin, A. (1995). Citizen science: a study of people, expertise and sustainable development. Routledge, London, UK.

Jones, M. G., Howe, A., and Rua, M. J. (2000). Gender differences in students' experiences, interests, and attitudes toward science and scientists. Science education 84(2): 180-192.

Keehner, M. and Fischer, M. H. (2011). Naive realism in public perceptions of neuroimages. Nat Rev Neurosci. 12: 118.

Peer) reviewing PDF | (2019:01:34668:1:1:NEW 24 Jun 2019) 
466

467

468

469

470

471

472

473

474

475

476

477

478

479

480

481

482

483

484

485

486

487

488

489

490

491

492

493

494

495

496

497

498

499

500

501

502

503

504

505
Kelemen-Finan, J., Scheuch, M. and Winter, S. (2018). Contributions from citizen science to science education: an examination of a biodiversity citizen science project with schools in Central Europe. Internat. Journal of Science Education, https://doi.org/10.1080/09500693.2018.1520405

Kotrschal, K. (2007). Konrad Lorenz Forschungsstelle: Northern Bald Ibis project 1997-2006: an Update. In: Northern Bald Ibis Conservation workshop report. Proc 2nd Meeting of the International Advisory Group for Northern Bald Ibis (IAGNBI). IAGNBI, Vejer, pp 64-66

Kremen C., Ullman, K.S. and Thorp, R.W. (2011). Evaluating the quality of citizen-scientist data on pollinator communities. Conserv Biol.; 25: 607-17. pmid:21507061

Leshner, A. I. (2003). Public engagement with science. Science 299: 977.

Medvecky, F. and Leach, J. (2017). The ethics of science communication. JCOM 16 (4), https://jcom.sissa.it/archive/16/04/JCOM 16042017 E.

Mitchell, N., Triska, M., Liberatore, A., Ashcroft, L., Weatherill, R. and Longnecker, N. (2017). Benefits and challenges of incorporating citizen science into university education. PLOS ONE 12(11): e0186285. https://doi.org/10.1371/journal.pone.0186285

Miczajka, V.L., Klein, A.-M., Pufal, G. (2015). Elementary School Children Contribute to Environmental Research as Citizen Scientists. PLOS ONE, 10(11): e0143229. doi:10.1371/journal.pone.0143229

Pardo, R., and Calvo, F. (2002). Attitudes toward science among the European public: a methodological analysis. Public Understanding of Science, 11(2), 155-195. https://doi.org/10.1088/0963-6625/11/2/305

Portugal, S. J., Hubel, T. Y., Fritz, J., Heese, S., Trobe, D., Voelkl, B., Hailes, S., Wilson, A. M., and Usherwood, J. R. (2014). Upwash exploitation and downwash avoidance by flap phasing in ibis formation flight. Nature, 505: 399. http://dx.doi.org/10.1038/nature12939.

Puehringer-Sturmayr, V., Wascher, C. A. F., Loretto, M.-C., Palme, R., Stoewe, M., Kotrschal, K., and Frigerio, D. (2018). Seasonal differences of corticosterone metabolite concentrations and parasite burden in Northern Bald Ibis (Geronticus eremita): The role of affiliative interactions. PLOS ONE, e0191441. doi.org/10.1371/journal.pone.0191441

Quevedo, M. A., Sánchez, I., Aguilar J. M., Cuadrado, M., and López J. M. (2004). A study of different release techniques for a captive population of NBI (Geronticus eremita) in the region of La Janda (Cádiz, southern Spain). In: 3o Newsletter of the International Advisory Group for the Northern Bald Ibis (IAGNBI) (ed.C.Böhm). Published by the IAGNBI

Racine, E., Bar-Ilan, O., and Illes, J. (2005). fMRI in the public eye. Nat Rev Neurosci. 6: 159-164.

Rauchfleisch, A. and Schäfer, M. S. (2018). Structure and development of science communication research: co-citation analysis of a developing field. JCOM 17 (03), A07.

https://doi.org/10.22323/2.17030207.

Ries, L., and Oberhauser, K. (2015). A Citizen Army for Science: Quantifying the Contributions of Citizen Scientists to our Understanding of Monarch Butterfly Biology. BioScience, 65(4): 419-430, https://doi.org/10.1093/biosci/biv011

R Core Team (2018). R: A language and environment for statistical computing. R Foundation for Statistical Computing, Vienna, Austria. URL https://www.R-project.org/.

Rogoff, B., Callanan, M., Gutiérrez, K., and Erickson, F. (2016). The Organization of Informal Learning. Review of Research in Education, 40: 356-401. doi:10.3102/0091732×16680994.

Peer) reviewing PDF | (2019:01:34668:1:1:NEW 24 Jun 2019) 
506 Satterthwait, D. (2010). Why are 'hands-on' science activities so effective for student learning? Teaching Science: The Journal of the Australian Science Teachers Association 56(2), 7-10.

508 Schmeller, D. S., Henry, P., Julliard, R., Gruber, B., Clobert, J., Dziock, F., Lengyel, S., Nowicki, P., Déri, E., 509 Budrys, E., Kull, T., Tali, K., Bauch, B., Settele, J., Van Swaay, C., Kobler, A., Babij, V., Papastergiadou, E., 510 and Henle, K. (2009). Advantages of Volunteer-Based Biodiversity Monitoring in Europe. Conservation 511 Biology, 23: 307-316. doi:10.1111/j.1523-1739.2008.01125.x

512 Sjøberg, S., and Schreiner, C. (2005). How do learners in different cultures relate to science and 513 technology? Results and perspectives from the project ROSE (The Relevance of Science Education). Asia514 Pacific Forum on Science Learning and Teaching, 6, 1-16.

515 Puehringer-Sturmayr V, Wascher CAF, Loretto M-C, Palme R, Stoewe M, Kotrschal K, and Frigerio, D. 516 (2018). Seasonal differences of corticosterone metabolite concentrations and parasite burden in 517 northern bald ibis (Geronticus eremita): The role of affiliative interactions. PLOS ONE, 13(1):e0191441.

518 doi: 10.1371/journal.pone.0191441

519 Shirk, J. L., Ballard, H. L., Wilderman, C. C. Phillips, T., Wiggins, A., Jordan, R., McCallie, E., Minarchek, M., Lewenstein, B. V., Krasny, M. E., and Bonney, R. (2012). Public participation in scientific research: a framework for deliberate design. Ecology and society 17, 29 pages. http://dx.doi.org/10.5751/ES-04705522170229.

523 Tintner, A., and Kotrschal, K. (2002). Early social influence on nestling development in Waldrapp ibis 524 (Geronticus eremita). Zoo Biology, 21(5), 467-480. doi.org/10.1002/zoo.10050.

525 Trumbull, D. J., Bonney, R., Bascom, D. and Cabral, A. (2000). Thinking scientifically during participation

526 in a citizen-science project. Science education 84 (2), 265-275

527 Trumbull, D. J., Bonney, R., Grudens-Schuck, N. (2005). Developing materials to promote inquiry: Lessons 528 learned. Science education 89 (6), 879-900

529 Tuckova, K., Zisser, B., and Kotrschal, K. (1998): Versuch der Ansiedlung einer ortsfesten Waldrapp-

530 Kolonie an der Konrad-Lorenz-Forschungsstelle. ÖKO.L 20(3): 3-1.

531 van der Sanden, M. C. A. and Flipse, S. M. (2016). Science communication forHow to citeuncertain 532 science and innovation. JCOM 15 (06), C05.

533 Wickham, H. (2016). ggplot2: Elegant Graphics for Data Analysis. Springer-Verlag New York.

534 Wiggins, A., and Crowston, K. (2011). From conservation to crowdsourcing: a typology of citizen science. 535 Proceedings of the $44^{\text {th }}$ Hawaii International Conference on System Sciences (HICSS 2011). DOI:

536 10.1109/hicss.2011.207.

537 Wilde M., Hußmann, J. S., Lorenzen, S., Meyer, A., and Randler, C. (2012). Lessons with living harvest 538 mice: an empirical study of their effects on intrinsic motivation and knowledge acquisition. Int. J. Sci. 539 Educ., 34(18): 2797-2810. doi: 10.1080/09500693.2012.654829

540 Wilkinson, C. (2018). Ethics and practice in science communication. JCOM 17 (04), R02.

541 https://doi.org/10.22323/2.17040702.

542

543 


\section{Acknowledgements}

546 We gratefully acknowledge C. Baer for inserting the data and J. Hemetsberger for technical support.

547 Special thanks to J. Sieberer, R. Witmann, B. Leberbauer and their pupils (school years 2011/2012 and

548 2015/2016) from the Primary Schools in Gruenau im Almtal and Scharnstein-Muehldorf for the excellent

549 collaboration.

550

\section{Funding}

552 Verena Puehringer-Sturmayr was funded by the Programme Sparkling Science, Project SPA-05/26 and by

553 the Programme Top Citizen Science, Project TCS-02/06. Didone Frigerio was funded by the Programme

554 Sparkling Science, Project SPA-05/26 and by the "Back-to-Research-Grant" of the University of Vienna,

555 Faculty of Life Sciences. Gudrun Gegendorfer was sponsored by the company Mayr Schulmöbel.

556 Permanent support came from the "Verein der Förderer der Konrad Lorenz Forschungsstelle" and the

557 "Herzog von Cumberland Stiftung".

558

\section{Author contributions}

560 The manuscript contains only material that is either original and has not been published or submitted

561 elsewhere or stems from publications identified by a reference. All authors have seen the final

562 manuscript and take responsibility for its contents.

563 DF, KK and GG conceived the questionnaire for the investigation year 2012. DF, KH and BNH conceived

564 the questionnaire for the investigation year 2016. DF, VPS and GG supported the schools in conducting

565 the interviews. DF and VPS performed the analysis. DF wrote the manuscript and reviewed every draft

566 of it. All co-authors always contributed and commented on each draft of the manuscript.

567

Peer] reviewing PDF | (2019:01:34668:1:1:NEW 24 Jun 2019) 


\section{Competing interests}

569 The authors have no competing interests to declare.

570 


\section{Table $\mathbf{1}$ (on next page)}

List of the questions and their relative answers available in the questionnaire in both years of investigation $(2012,2016)$.

Please note that at the time of data collection NBI was still classified as critically endangered (downgraded to "endangered" in summer 2018; query 2, focus 1). 
Table 1:

2

\begin{tabular}{|c|c|c|c|}
\hline $\begin{array}{l}\text { Investigation year } \\
\text { Questions }\end{array}$ & $\begin{array}{l}2012 \\
\text { possible answers }\end{array}$ & $\begin{array}{l}2016 \\
\text { possible answers }\end{array}$ & $\begin{array}{l}2012 \text { and } 2016 \\
\text { correct answer }\end{array}$ \\
\hline \multicolumn{4}{|l|}{ Focus 1: general knowledge on NBI } \\
\hline 1. NBI are colony breeders & $\begin{array}{l}\text { 1. Yes, no, I do not } \\
\text { know }\end{array}$ & $\begin{array}{l}\text { 1. Yes, rather yes, no, } \\
\text { rather no, I do not know }\end{array}$ & 1. Yes \\
\hline 2. NBI are critically endangered & $\begin{array}{l}\text { 2. Yes, no, I do not } \\
\text { know }\end{array}$ & $\begin{array}{l}\text { 2. Yes, rather yes, no, } \\
\text { rather no, I do not know }\end{array}$ & 2. Yes \\
\hline $\begin{array}{l}\text { 3. Adult NBI have feathers on } \\
\text { their heads, juveniles not }\end{array}$ & $\begin{array}{l}\text { 3. Yes, no, I do not } \\
\text { know }\end{array}$ & 3. Yes, no, I do not know. & 3. No \\
\hline
\end{tabular}

Focus 2: specific knowledge on the local NBI population

\begin{tabular}{|c|c|c|c|}
\hline $\begin{array}{l}\text { 4. The local Almtal NBI colony } \\
\text { spends the winter in the South. }\end{array}$ & $\begin{array}{l}\text { 4. Yes, no, I do not } \\
\text { know }\end{array}$ & $\begin{array}{l}\text { 4. Yes, rather yes, no, } \\
\text { rather no, I do not know }\end{array}$ & 4. No \\
\hline $\begin{array}{l}\text { 5. Birds of the local NBI colony } \\
\text { can be easily observed on the } \\
\text { meadows around the villages } \\
\text { of Gruenau and Scharnstein. }\end{array}$ & $\begin{array}{l}\text { 5. Yes, no, I do not } \\
\text { know }\end{array}$ & 5. Yes, no, I do not know & 5. Yes \\
\hline $\begin{array}{l}\text { 6. I feel well informed about } \\
\text { the local NBI colony. }\end{array}$ & $\begin{array}{l}\text { 6. Yes, no, I do not } \\
\text { know }\end{array}$ & $\begin{array}{l}\text { 6. Yes, rather yes, no, } \\
\text { rather no, I do not know }\end{array}$ & 6. Not applicable \\
\hline \multicolumn{4}{|c|}{ Additional focus 3 (only 2016): attitude towards science } \\
\hline $\begin{array}{l}\text { 7. Is science important for the } \\
\text { society? }\end{array}$ & 7. Not available & $\begin{array}{l}\text { 7. Yes, rather yes, no, } \\
\text { rather no }\end{array}$ & 7. Yes \\
\hline
\end{tabular}




\begin{tabular}{|l|l|l|l|}
\hline $\begin{array}{l}\text { 8. Is conservation important } \\
\text { for the society? }\end{array}$ & 8. Not available & $\begin{array}{l}\text { 8. Yes, rather yes, no, } \\
\text { rather no }\end{array}$ & 8. Yes \\
$\begin{array}{l}\text { 9. Do you trust scientific } \\
\text { findings? }\end{array}$ & $\begin{array}{l}\text { 9. Not available. } \\
\text { 9. Yes, rather yes, no, } \\
\text { rather no }\end{array}$ & 9. Not applicable \\
\hline
\end{tabular}

3 


\section{Table 2 (on next page)}

Proportions of children and adults assigning high importance for science and conservation, and their perceived trust in scientific findings (focus 3 "attitude towards science") in the 2016 survey. 
1 Table 2:

2

\begin{tabular}{|l|c|c|}
\hline Questions & Children & Adults \\
\hline Query 7: & $(\mathrm{N}=156)$ & 93.87 \\
Is science important for the society? & 95.45 & \\
\hline Query 8: & 94.84 & 98.16 \\
\hline Is conservation important for the society? & & 86.59 \\
\hline Query 9: & 83.23 & \\
\hline Do you trust scientific findings? & & \\
\hline
\end{tabular}

3

4 
Figure $\mathbf{1}$ (on next page)

Results in percent change of the answers given by adults in both years 2012 and 2016 for the focus 1 "general knowledge on the NBI".

(A) query 1: NBI are colony breeders; (B) query 2: NBI are critically endangered; (C) query 3: adult NBI have feathers on their heads, juveniles do not. Bars underneath the zero line indicate lower rates in 2016 than in 2012; bars above zero line specify higher rates in 2016 than in 2012. 


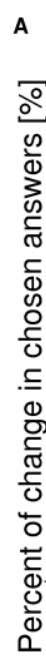

A
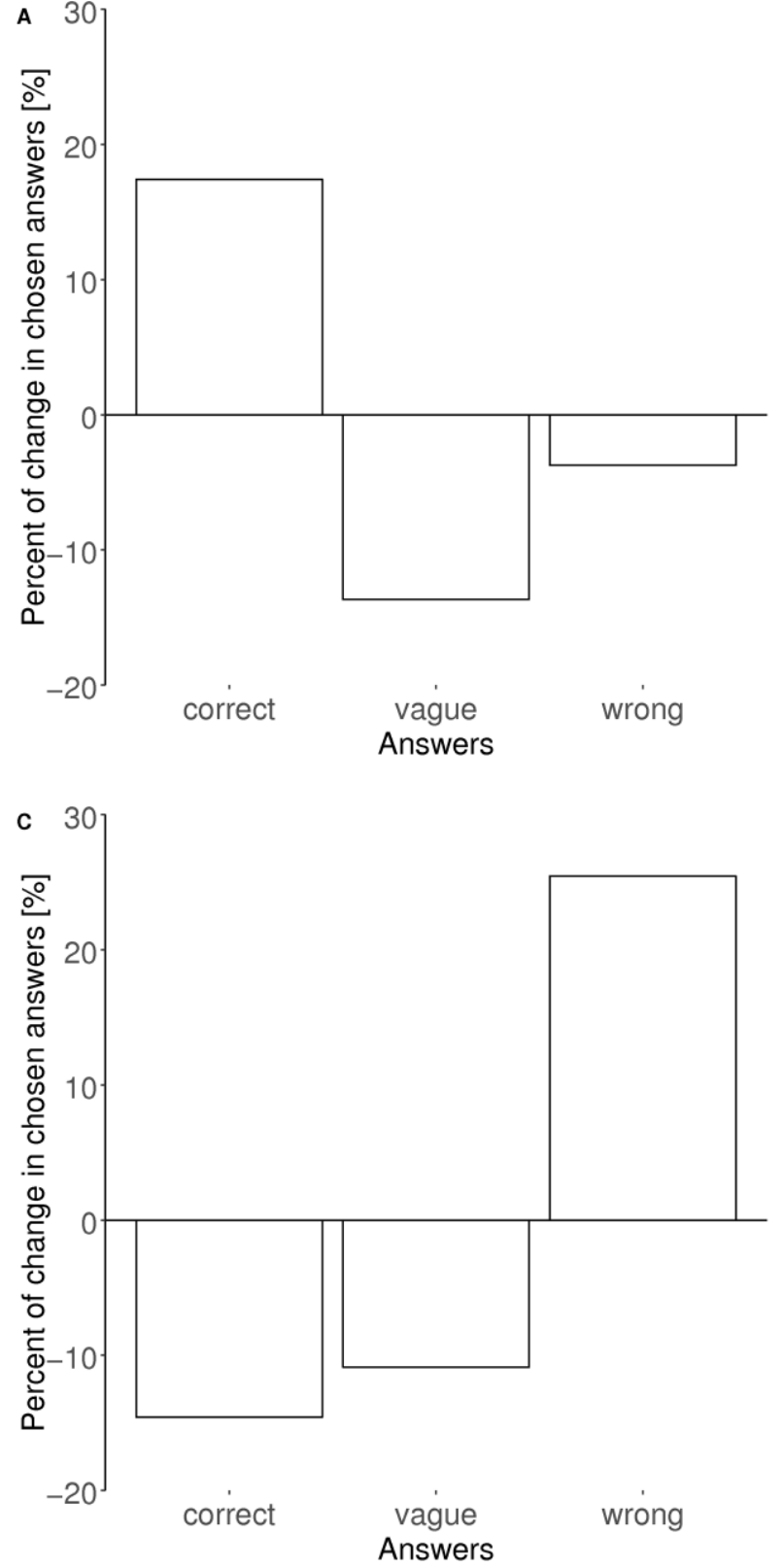

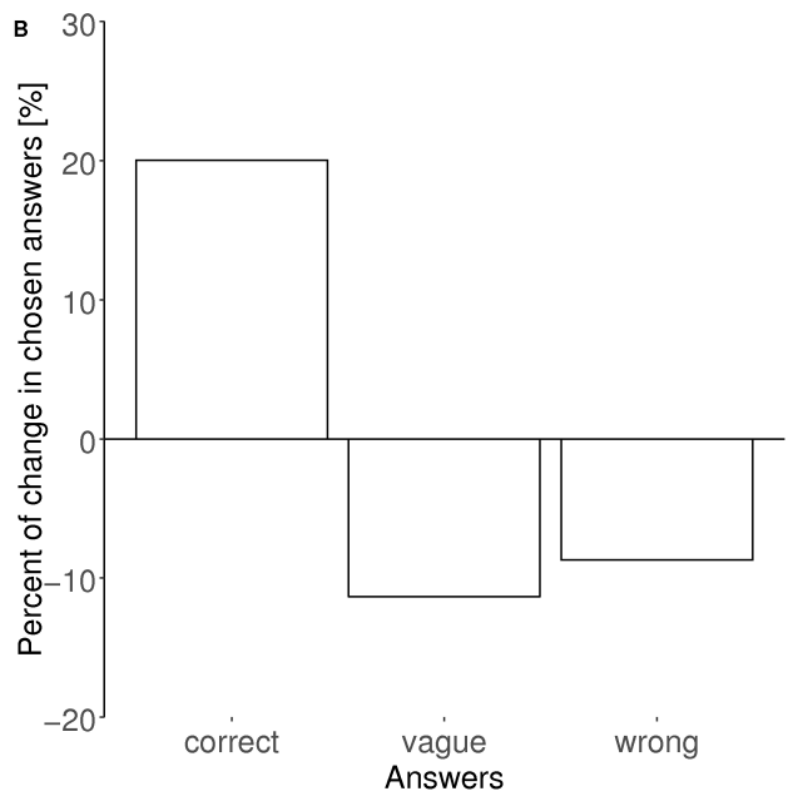


Figure 2 (on next page)

Percentage change of the answers given by adults in both years of evaluation 2012 and 2016 for the focus 2 "specific knowledge on the local NBI population".

(A) query 4: the local Almtal NBI colony spends the winter in the South; (B) query 5: birds of the local NBI colony can be easily observed on the meadows around the area. Bars underneath the zero line indicate lower rates in 2016 than in 2012; bars above zero line specify higher rates in 2016 than in 2012. 

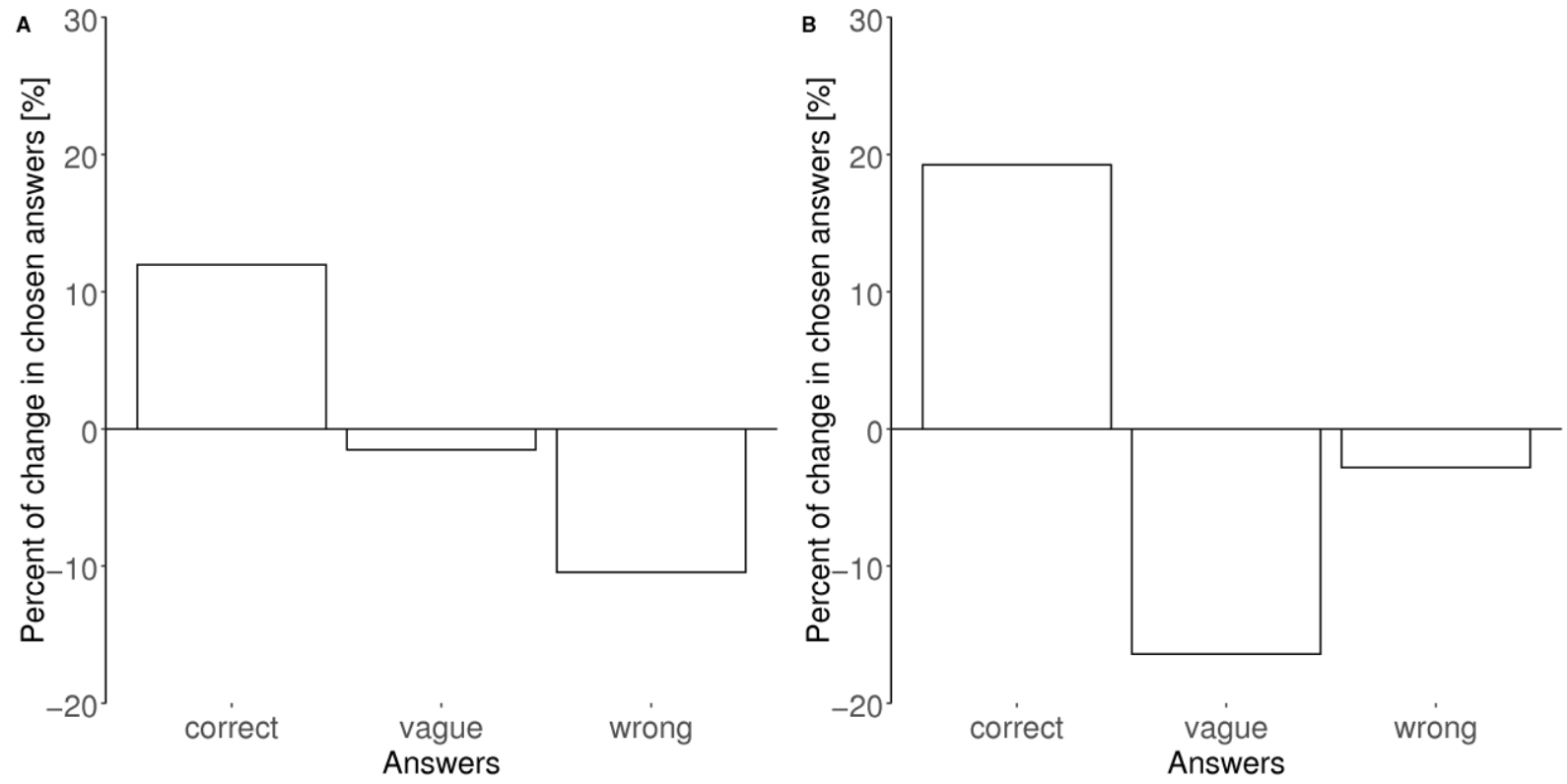
Figure 3 (on next page)

Proportions of the answers given by children in 2016 about their general $(A-C)$ and specific (D-E) NBI knowledge.

(A) query 1: NBI are colony breeders; (B) query 2: NBI are critically endangered; (C) query 3: adult NBI have feathers on their heads, juveniles not; (D) query 4: the local Almtal NBI colony spends the winter in the South; (E) query 5: the birds of the local NBI colony can be easily observed on the meadows around the villages of the area. Black = correct answers; grey = vague answers (I do not know); light grey = wrong answers. 

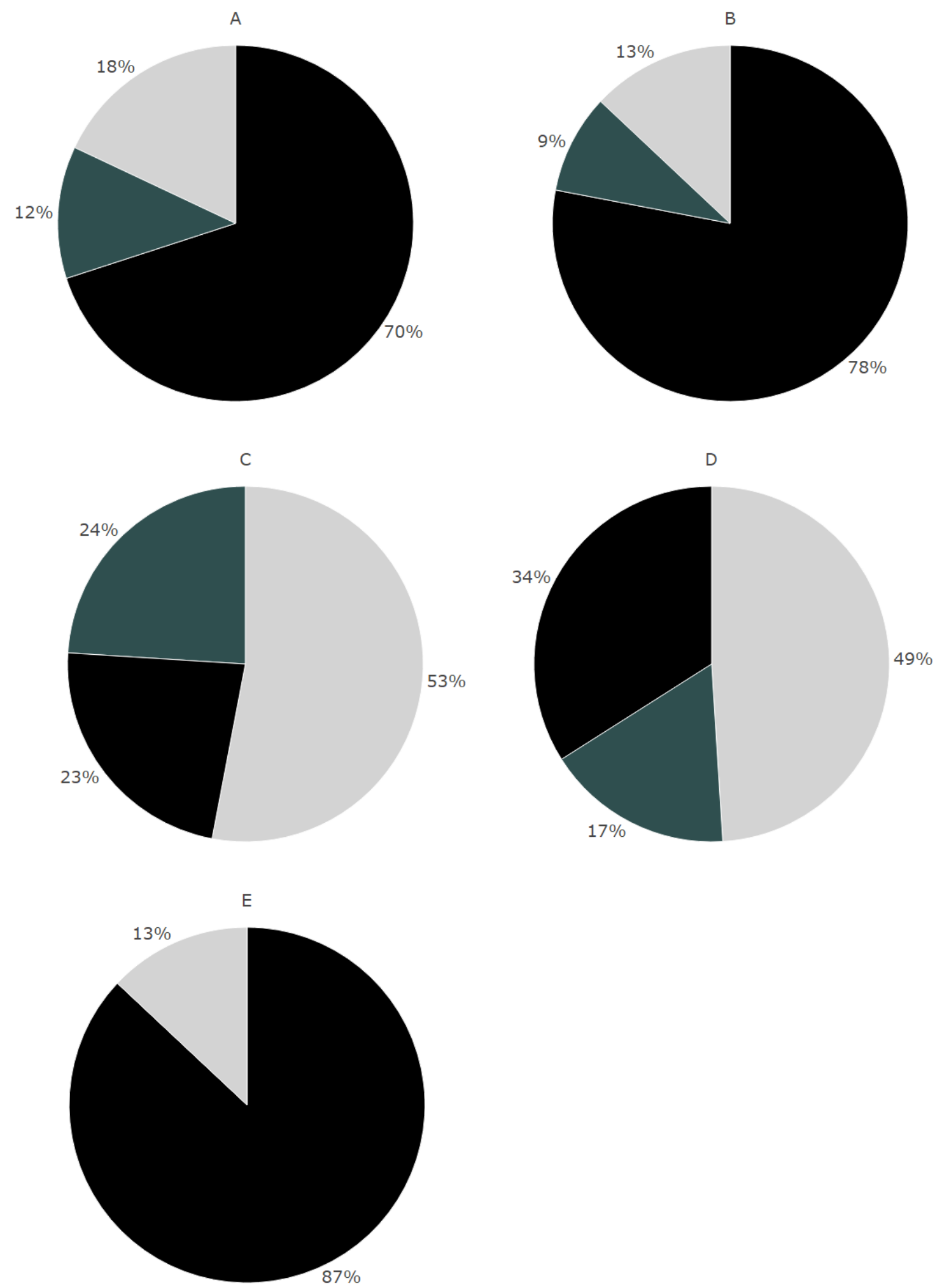


\section{Table 3(on next page)}

Model selection from the generalized linear models. The parameters explaining the response variables (single queries) are provided. 
1

2

\begin{tabular}{|c|c|c|c|}
\hline Response variable & Model & AIC & $p$-value \\
\hline \multirow[t]{2}{*}{ query 1} & Intercept only & 122.675 & \\
\hline & query $3 *$ year & 125.621 & 0.257 \\
\hline \multirow[t]{2}{*}{ query2 } & Intercept only & 167.389 & \\
\hline & query $3 *$ year & 167.387 & 0.083 \\
\hline \multirow[t]{2}{*}{ query 3} & Intercept only & 315.250 & \\
\hline & query $3 *$ year & 309.179 & 0.006 \\
\hline \multirow[t]{2}{*}{ query 4} & Intercept only & 310.186 & \\
\hline & query $3 *$ year & 315.196 & 0.518 \\
\hline \multirow[t]{2}{*}{ query 5} & Intercept only & 112.374 & \\
\hline & query $3 *$ year & 110.457 & 0.038 \\
\hline \multirow[t]{2}{*}{ query 6} & Intercept only & 314.453 & \\
\hline & year & 312.805 & 0.055 \\
\hline
\end{tabular}

Table 3:

2
3

4 


\section{Table 4(on next page)}

Model coefficients of final models.

The coefficients including standard errors (SE), z-value and p-value are provided. 
1 2

\begin{tabular}{|c|c|c|c|c|c|c|}
\hline $\begin{array}{l}\text { Response } \\
\text { variable }\end{array}$ & $\begin{array}{l}\text { Final } \\
\text { model }\end{array}$ & Coefficients & Estimate & SE & z-value & $\mathrm{p}$-value \\
\hline \multirow[t]{6}{*}{ query 3} & $\begin{array}{l}\text { query } \\
3 * \text { year }\end{array}$ & Intercept & 0.642 & 0.391 & 1.643 & 0.100 \\
\hline & & query 3 (no) & 0.680 & 0.685 & 0.992 & 0.321 \\
\hline & & $\begin{array}{l}\text { query } 3 \text { (not } \\
\text { sure) }\end{array}$ & -0.103 & 0.616 & -0.167 & 0.867 \\
\hline & & year (2016) & -0.796 & 0.444 & -1.794 & 0.073 \\
\hline & & $\begin{array}{l}\text { query } 3 \\
(\text { no)*year } \\
(2016)\end{array}$ & -0.944 & 0.758 & -1.244 & 0.213 \\
\hline & & $\begin{array}{l}\text { query3 (not } \\
\text { sure)*year } \\
\text { (2016) }\end{array}$ & NA & NA & NA & NA \\
\hline \multirow[t]{2}{*}{ query 5} & $\begin{array}{l}\text { query } \\
3 * \text { year }\end{array}$ & Intercept & 2.159 & 0.610 & 3.542 & $<0.001$ \\
\hline & & query 3 (no) & -0.019 & 0.965 & -0.020 & 0.984 \\
\hline
\end{tabular}




\begin{tabular}{|c|c|c|c|c|c|}
\hline & $\begin{array}{l}\text { query } 3 \text { (not } \\
\text { sure) }\end{array}$ & 0.731 & 1.195 & 0.612 & 0.541 \\
\hline & year (2016) & 2.340 & 1.176 & 1.990 & 0.047 \\
\hline & $\begin{array}{l}\text { query } 3 \\
(\text { no })^{*} \text { year } \\
(2016)\end{array}$ & -2.465 & 1.443 & -1.708 & 0.088 \\
\hline & $\begin{array}{l}\text { query } 3 \text { (not } \\
\text { sure)*year } \\
\text { (2016) }\end{array}$ & NA & NA & NA & NA \\
\hline
\end{tabular}

3 